\title{
CULTURA NACIONAL COMO COMUNIDADE FILMADA: REPRESENTAÇÕES DA NACIONALIDADE NO CINEMA BRASILEIRO
}

\author{
Marcos Cezar Botelho ${ }^{1}$
}

\begin{abstract}
Resumo: A reiteração das representações da nacionalidade em filmes e na cultura midiática em geral indicia a viabilidade da nação como uma categoria persistente - embora mais evanescente e menos sólida do que na era moderna - de análise da cultura. Mesmo que seu centro produtor de identificações, o Estado-Nação, tenha perdido a força de homogeneização e persuasão política, a narrativa da nação, em meio à problemática das identidades coletivas no mundo globalizado, continua sendo reescrita e debatida no cinema brasileiro contemporâneo.

Palavras-Chave: Cinema; Cultura; Identidade Nacional.
\end{abstract}

Resumen: La reiteración de las representaciones de la nacionalidad en el cine y en los medios de comunicación en general indican la viabilidad de la nación como una categoria persistente - aunque más evanescente y menos sólida de lo que en el período moderno - del análisis de la cultura. Incluso si su centro productor de identificaciones, el Estado-Nación, tenga perdido su fuerza de homogeneización y persuasión politica, la narrativa de la nación, en medio al problema de las identidades colectivas en el mundo globalizado, continuan siendo reescritos y debatidos en el cine brasileño contemporáneo. Palabras-Clave: Cine; Cultura; Identidad nacional.

\section{INTRODUÇÃO}

As lutas da história não se restringem a soldados e canhões, mas abrangem também idéias, formas, imagens e representações (Edward Said).

Na esquina entre os séculos 19 e 20, a arte do cinematógrafo, com seu ritmo fragmentado e de impacto imediato, representava, no plano das

1 Mestre em Literatura e Diversidade Cultural pela Universidade Estadual de Feira de Santana (UEFS); doutorando do Programa de Pós-Graduação em Literatura e Cultura da Universidade Federal da Bahia (UFBA), sob a orientação do Prof. Dr. Sandro Ornellas; professor de Literatura Brasileira, Estudos Culturais e Estética e Linguagem Audiovisual do Centro Universitário Jorge Amado (UNIJORGE); co-organizador, com Claudio C. Novaes, de Seis passeios por Cidade de Deus (2007). Endereço eletrônico: marcosbotelho.br@ gmail.com. 
linguagens, o equivalente das experiências de choques vividas pelos sujeitos no pico da primeira onda tecnológica na cidade moderna. Walter Benjamin, por exemplo, pensava o cinema como um dos agentes que alterou radicalmente a tradição na modernidade, acelerando a passagem pós-aurática das artes na "era da reprodutibilidade técnica". Em seu ensaio mais influente, Benjamin anotou:

nas obras cinematográficas, a reprodutibilidade técnica do produto não é, como no caso da literatura ou da pintura, uma condição externa para a sua difusão maciça. A reprodutibilidade técnica do filme tem seu fundamento imediato na técnica de sua produção. Esta não apenas permite, da forma mais imediata, a difusão em massa da obra cinematográfica, como a torna obrigatória. A difusão se torna obrigatória, porque a produção de um filme é tão cara que um consumidor, que poderia, por exemplo, pagar um quadro, não pode mais pagar um filme. O filme é uma criação coletiva (BENJAMIN, 1985, p. 172).

Na grande narrativa da modernidade, há também outra importante criação coletiva sempre em cartaz nas telas do cinema: a nação. Robert Stam articula o aparecimento do cinema ao auge das nações expansionistas que fundaram "os grandes impérios europeus, numa época em que a Europa tinha ascendência sobre grandes extensões de territórios estrangeiros e hostes subjugados" (1996, p. 201). A arte cinematográfica, assim como a narrativa da nação, também nos interpela a partir de representações e discursos de pertencimentos identitários. Conforme Stam, "o cinema como contador de histórias do mundo por excelência era [é] o veículo ideal para transmitir as lendas de nações e impérios, assumindo assim um papel decisivo no fomento das identidades" (1996, p. 201). O autor lembra ainda que, além da onipresença das mídias proporcionada pela mundialização da cultura, as imagens audiovisuais levam uma vantagem em relação a outras formas de representação: elas podem até mesmo prescindir da alfabetização do espectador e, "como entretenimento popular, são mais acessíveis que a literatura" (1996, p. 201). Não por acaso, Vladimir Lênin viu no cinema o meio de disseminação mais eficiente de construção do Estado socialista na Rússia pós-1917. "De todas as artes", escreveu Lênin em 1922, "a mais importante para nós é o cinema" (COUSINS, 2004, p. 102). Em uma sociedade de maioria não-letrada, acreditava Lênin, a linguagem cinematográfica seria uma arma social e a ponte mais acessível entre a população dispersa e a demanda pela reinvenção da identidade nacional. Oitenta anos após a revolução, foi justamente o cinema que melhor representou o declínio do 
socialismo, a falência das antigas utopias e a unificação das Alemanhas, em um filme com o sugestivo título: Adeus, Lênin! ${ }^{2}$

Com a chamada "virada linguística" e a constatação de que a narrativa é crucial na construção das identidades, passou-se a pensar a nação, nas últimas décadas, como uma "comunidade imaginada e narrada". Segundo Benedict Anderson, a nação é imaginada porque mesmo os cidadãos/ãs da mais "minúscula das nações jamais conhecerão, encontrarão, ou sequer ouvirão falar da maioria dos seus companheiros, embora todos tenham em mente a imagem viva da comunhão entre eles" (2008, p. 32). Ou seja: a nação é um construto baseado na invenção de uma identidade compartiIhada e do sentimento de pertença, que preenche um espaço geopolítico a partir de uma tela de representações e símbolos. Assim, deslocada para o plano da discursividade, a compreensão do que seja a nação escapa aos essencialismos do tipo biológico ou racial, já que a identidade nacional passa a ser entendida como uma pedagogia produzida e fixada pelos discursos nas esferas públicas e não como algo inerente ao nosso DNA. Stuart Hall, retomando Anderson, pensa as construções identitárias com base no pressuposto de que não existe identidade fora da representação. Para ele, as identidades nacionais são metáforas,

pois não são coisas com as quais nós nascemos, mas formadas e transformadas no interior da representação. Nós só sabemos o que significa ser "inglês" devido ao modo como a "inglesidade" (Englishness) veio a ser representada - com um conjunto de significados - pela cultura nacional inglesa. Segue-se que a nação não é apenas uma entidade política, mas algo que produz sentidos - um sistema de representação cultural. As pessoas não são apenas cidadãos/ãs legais de uma nação; elas participam da idéia da nação tal como representada em sua cultura nacional (HALL, 2006, p. 49. Grifos do autor).

Para Anderson, modernidade e nação não são antípodas. Ao contrário, o Estado-nação como forma "natural" de organização social é relativamente recente. Na verdade, as antigas formas de pertencimento anteriores à modernidade, o tribalismo, a família, a religião etc., migraram para a na-

2 Adeus, Lênin! foi dirigido por Wolfgang Becker, em 2003. No contexto da unificação das Alemanhas, entre 1989 e 90, conta a história bizarra de Alexander, cuja mãe, uma entusiasta do socialismo, sofre um infarto após presenciar uma passeata contra o regime socialista. Ela sai do coma após a queda do muro de Berlim. Alexander, por conta da saúde fragilizada da mãe, tenta manter a vida e a paisagem da Berlim Oriental, como se esta não tivesse desaparecido. Para tal, utilizará significativamente a linguagem audiovisual, inventando noticiários e programas de televisão, nos quais encena o sonho da vitória socialista para a mãe enferma.

Cláudio Cledson Novaes, Fernanda Aguiar C. Martins, Roberto H. Seidel (Org.) 
ção moderna que, ambiguamente, agiu como catalisador das diferenças antes restritas a âmbitos mais estreitos da experiência identitária. Como exemplos de emergência das técnicas massivas e modernas de reprodução, Anderson destaca a importância do romance folhetim, da impressa, da fotografia, do jornal e da incipiente indústria cultural, na criação de um sentimento de "simultaneidade" necessário à experiência coletiva da identidade nacional. Para o autor, as descobertas sociais e científicas e o desenvolvimento de meios de comunicação massiva, cada vez mais velozes, levaram à

[...] busca, por assim dizer, de uma nova maneira de unir significativamente a fraternidade, o poder e o tempo. O elemento que talvez mais catalisou e fez frutificar essa busca foi o capitalismo editorial, que permitiu que as pessoas, em números sempre maiores, viessem a pensar sobre si mesmas e a se relacionar com as demais de maneiras radicalmente novas (ANDERSON, 2008, p. 70).

Ora, a irrupção do cinema e da indústria cultural será central na construção do imaginário social das nações modernas. Entre os aspectos mais importantes nos modos como a nação é inventada, Stuart Hall destaca, em primeiro lugar, a narrativa da nação tal

como é contada e recontada nas histórias e nas literaturas nacionais, na mídia e na cultura popular. Essas fornecem uma série de estórias, imagens, panoramas, cenários, eventos históricos, símbolos e rituais nacionais que simbolizam ou representam as experiências partilhadas, as perdas, os triunfos e os desastres que dão sentido à nação. Como membros de tal "comunidade imaginada", nos vemos, no olho de nossa mente, como compartilhando dessa narrativa. Ela dá significado e importância à nossa monótona existência, conectando nossas vidas cotidianas com um destino nacional que preexiste a nós e continua existindo após nossa morte (HALL, 2006, p. 52).

Neste ensaio, os filmes são lidos como narrações e enunciados da nação, que nos permitem mapear parte das relações entre sociedade e imaginário nacional no Brasil. A ideia é possibilitar algumas direções de decodificação do cinema como lugar discursivo que interpreta e também inventa o Brasil. O cinema e o audiovisual não são meros meios de registro transparente da realidade. Como outros modos de representação, também constroem e "re-apresentam" o mundo por meio de códigos, mitos e ideologias da cultura. Creio que os textos midiáticos, nas práticas pedagógicas atuais, não podem mais ser encarados como meras ilustrações ou apêndices do texto escrito, primos pobres da literatura presos ao platonismo enrustido que cobra da ficção midiática a "fidelidade ao livro" ou a "fatos históricos", 
mas como expressões autônomas que potencializam novas competências para ver e analisar a formação das subjetividades em nossa "idade mídia".

\section{A CARTA, A TELA, OS FILMES: (RE)INVENÇõES DO MITO DE FUNDAÇÃo DA NACIONALI- DADE}

Nas narrativas da nação, o ato inaugural da identidade, aquele instante escolhido posteriormente como a "origem da nacionalidade", estabelece, no conjunto de suas histórias oficiais, o primeiro incidente dramático da genealogia nacional. Como imagem e gesto fundador, instaura uma continuidade entre o passado remoto e o presente da nação. O mito fundador é, portanto,

uma história que localiza a origem da nação, do povo e de seu caráter nacional num passado tão distante que eles se perdem nas brumas do tempo, não do tempo "real", mas de um tempo "mítico". Tradições inventadas tornam as confusões e os desastres da história inteligíveis, transformando desordem em comunidade (HALL, 2006, p. 55).

O "achamento do Brasil" narrado por Pero Vaz de Caminha, em 1500, foi descoberto no século 19 como resultado das demandas do Romantismo e do projeto de construção da nacionalidade que convergiram na época pós-independência. Como mito de fundação da história nacional, foi reconstruído a partir do arquivo produzido por viajantes e missionários nos primórdios da colonização. Cartas, relatos, gravuras, telas, sermões e textos historiográficos serviram de fontes aos historiadores e artistas empenhados na tarefa de narrar a nação como uma entidade coletiva. Dos textos que nos foram legados, $A$ Carta do achamento do Brasil, escrita por Caminha ao Rei D. Manuel, se estabeleceu como "a certidão de nascimento do Brasil". Até o século 19, a "reportagem" de Caminha, escrivão da esquadra de Pedro Álvares Cabral, não teve grande importância, sendo publicada somente em 1817. A Carta fixou-se em nosso imaginário como "fonte da protocena da identidade nacional" e do seu ato mítico inaugural. Para Eneida Leal Cunha (1995, p. 19),

nela podemos encontrar, se não a origem das coisas, da literatura ou da brasilidade, certamente alguns possíveis começos de significações culturais que ainda hoje retornam, como uma repetição compulsiva e permanente, embora sempre diferenciada, de uma mesma cena, ou talvez cenas que são matrizes da identidade pós-colonial. Talvez mais que isso. É possível que possamos reconhecer, no texto de Caminha, estruturas de percepção e de constituição 
de imagens do país que maquinalmente ainda estejamos repetindo: a compulsão ao olhar exteriorizado, plano e generalizante, a incapacidade de interlocução com a diversidade cultural, a vontade de tudo integrar em uma harmonia redutora.

Não por acaso a sequência mais retomada do relato de Caminha é aquela que ficou conhecida como "A Primeira Missa no Brasil". Esta é, na estrutura dramática do texto, a "segunda missa" narrada pelo escrivão, já que antes os membros da esquadra cabralina já haviam assistido a outra cerimônia religiosa, realizada na "Coroa Vermelha" próxima ao continente, mas sem a participação dos índios. Na "segunda missa", é a "inclusão" dos indígenas, que participam à margem da cruz, bem como a descrição interessada que Caminha faz do comportamento destes durante o ritual, que define a "segunda missa" como a "Primeira Missa do Brasil", por conta, é claro, da representação "conciliatória" e "harmoniosa" do contato entre europeus e indígenas, católicos e pagãos - estes tomados mais adiante, pelo indianismo romântico do século 19 , como os legítimos ancestrais da nação.

No intrincado processo de invenção da nacionalidade, a historiografia, a literatura e as artes visuais foram vitais à criação de "realidades" míticas para o imaginário nacional. A tela Primeira Missa no Brasil, composta por Victor Meirelles em 1861, retomando a cena da missa descrita na Carta, teve importância expressiva na fixação do mito fundador do Brasil. Meirelles tinha uma missão ambiciosa: oferecer pictoricamente ao Brasil o instante de seu nascimento. O pintor fez, conforme Jorge Coli (1998, p. 107),

com que o Descobrimento tomasse corpo imagético e se instalasse no interior de nossa cultura. Assim, revela-se um excelente objeto de análise para a compreensão de procedimentos artísticos que dependem, em sua própria origem, das contribuições originadas no projeto ideológico mais geral, na própria natureza de uma história capaz de engendrar o passado que se deseja [...] no sentido de conferir aos construtos resultantes uma força afetiva de persuasão e de certeza.

Sete décadas depois de Meirelles, o diretor Humberto Mauro, em Descobrimento do Brasil (1937), realiza a mais conhecida investida do cinema brasileiro na tentativa de fixação do "nascimento da nação". O realizador mineiro retoma $A$ Carta de Caminha e reencena a Primeira Missa, pondo em movimento a composição da tela de Meirelles, no contexto do nacionalismo de Getúlio Vargas, na década de 1930. Inspirado na experiência de Mussolini de fomento ao cinema como meio de difusão ideológica do ideário nacionalista, Vargas incentivou a produção de filmes educativos e 
históricos que levassem ao espectador os acontecimentos emblemáticos da conciliação com o passado heroico da nação. O projeto previa uma série de filmes sobre a epopeia dos bandeirantes, as missões jesuíticas, os conflitos em torno da independência e, é claro, a reconstituição do descobrimento.

\begin{abstract}
Estampar, desse modo, na tela do cinema, o momento mítico do encontro entre portugueses e índios, já instituídos como primeiros ascendentes do povo brasileiro, constituía, para o projeto nacionalista do governo Vargas, mais uma forma de reforçar a idéia da nação como uma grande família e a figura de seu dirigente como pai protetor (OLIVEIRA, 2004, p. 101).
\end{abstract}

Ao retomar a composição de Meirelles, Mauro dá curso à reiteração compulsiva da história oficial em sua busca pela imagem conciliatória da nacionalidade. $\mathrm{O}$ uso da tela de Meirelles - obrigatória nos livros didáticos de História - e de fontes oficiais no filme, como afirma Sheila Schvarzman, é "a caução da verdade ali restituída. O cinema agrega à verdade do documento consagrado a verdade da imagem em movimento" (SCHVARZMAN, 2004 , p. 154). Ao se colocar na formação discursiva da "história dos vencedores", o lócus enunciativo da câmera de Mauro, pode-se dizer, não faz qualquer contraponto ao discurso eurocêntrico, tanto da Carta quanto da tela, mas, ao contrário, procura posicionar-se a partir do olhar unilateral de Caminha repetido por Meirelles.

Na composição dos planos e angulações do filme, Mauro opta por uma mise-en-scène hierárquica que reforça a superioridade dos europeus - quase sempre enquadrados no centro das imagens em câmeras baixas de forma a engrandecê-los e a reforçar sua importância - e a subserviência dos indígenas, que aparecem como estranhos ao próprio espaço e "são representados como crianças-gentios: aqueles que ainda não sabem" (SCHVARZMAN, 2004, p. 158). Na relação dos índios com o meio ambiente, em vários momentos, estes

coçam-se, como se incomodados por insetos. Já os conquistadores, dos oficiais aos marujos, parecem imunes a estes, e mesmo o calor não os faz despir uma peça sequer do seu vestuário bastante pesado para o clima tropical em que se encontram. Os índios, ao contrário, parecem inadaptados ao lugar em que vivem, uma observação privilegiada pela câmera. Os índios dançam e não produzem. São coletores, e a ausência de trabalho é enfatizada nas sequências em que os portugueses medem a terra, cortam madeira enquanto os índios dançam (SCHVARZMAN, 2004, p. 58).

Mesmo ambientado na cena do achamento de 1500, o filme Descobrimento do Brasil traduz, ambiguamente, o presente em que foi realizado, o período Vargas, etapa fundamental da modernidade brasileira, com seu 
projeto de educação regido pelos "novos civilizadores", repetindo - sem o suplemento da diferença - a busca compulsória pela fixação da matriz mítica da identidade nacional iniciada no século 19, a qual o filme legitima e reforça.

\section{REVISÕES CARNAVALIZADAS DO MITO DE FUNDAÇÃO NACIONAL}

Se a recriação do passado pelo cinema pode repetir a lógica etnocêntrica para reafirmar no presente a pedagogia da história oficial, outros filmes retomaram o mito de fundação da nação questionando a perspectiva central da conquista, a partir da ótica dialógica da alegoria ou da paródia. Tal estratégia discursiva visa deslocar o eixo das representações normativas para uma história alternativa "vista a partir de baixo".

Em Terra em Transe (1967), Glauber Rocha apropria-se do texto canônico do "descobrimento", desconstruindo alegoricamente as representações pedagógicas do nascimento da nação. Surgido no âmbito dos movimentos artísticos que, no Brasil, procuraram diagnosticar a nacionalidade à luz da condição periférica e do impacto do golpe militar de 1964, o filme, ambientado em Eldorado, país "interior e imaginário" que metaforiza a América Latina, centra-se na trajetória delirante - narrada em um longo flashback - do poeta e jornalista Paulo Martins. Ferido de morte, depois de furar um bloqueio do exército, Paulo revive os momentos que antecederam a crise política e existencial eclodida após um golpe federal, liderado pelo líder fascista Porfírio Diaz, contra o governador Vieira, um político populista que contava com o apoio da intelectualidade, mas renunciara à resistência armada proposta por Paulo.

Em uma sequência especial do filme, Glauber Rocha recria a cena do achamento em um tom assumidamente alegórico e anti-hollywoodiano. Vemos, em plano geral e em montagem descontínua, a figura de Porfírio Diaz "descobrindo o Brasil" em uma praia, carregando uma bandeira negra e um imenso crucifixo. A cerimônia apresenta os personagens em figurinos anacrônicos e carnavalizados. Diaz veste um terno preto característico dos dias atuais, enquanto um padre traja paramentos pesados e "medievais". Aquele que representa um "conquistador", interpretado pelo carnavalesco Clovis Bornay, veste uma fantasia com ornamentos exageradamente kitsch, enquanto um índio, interpretado por um mestiço, é estilizado à moda dos desfiles e paradas escolares. Na trilha sonora, a missa não é acompanhada por música sacra, mas por cânticos iorubá, evocando o apagamento da me20 Número temático: literatura e cinema. A Cor das Letras - UEFS, n. 11, 2010 
mória afro-descendente na história oficial do Brasil. Para Robert Stam (1996, p. 206),

Glauber desestabiliza ainda mais o significado ao tornar a África uma presença textual. A estética da seqüência, primeiramente, é emprestada das formas africanizadas das escolas de samba, com sua polirritmia, seus anacronismos, suas fantasias extravagantes; de fato, o ator que interpreta o conquistador é uma figura conhecida do carnaval do Rio. A referência de Glauber à música africana, como preexistente à chegada dos europeus, [...] sugere que os africanos, como os que moldaram e foram moldados pelas Américas, são de alguma forma misteriosa também da região.

Após aproximar-se da cruz, Diaz preside, mais uma vez, a "Primeira Missa", enfatizando, sob o efeito dos elementos anacrônicos, a continuidade entre a ação colonizadora e a opressão contemporânea, rasurando a visão totêmica do mito fundacional de Descobrimento do Brasil, de Humberto Mauro. No fundo, Glauber parece dizer: repetimos ainda hoje, no plano político, os mesmos gestos dos colonizadores.

Em Caramuru - A invenção do Brasil (2001), minissérie televisiva dirigida por Jorge Furtado e Guel Arraes ${ }^{3}$, a reescritura da memória nacional se dá sintonizada com a poética do pós-modernismo, na qual elementos de temporalidades distantes, estratégias intertextuais como o pastiche e a paródia, assim como a bricolagem de gêneros cinematográficos heterogêneos, se fundem em uma comédia que procura inverter com irreverência o eixo solene do descobrimento. A minissérie-filme pode ser lida como exemplo daquilo que Linda Hutcheon chama de metaficção historiográfica pós-moderna, uma estratégia ficcional de reelaboração das formas e conteúdos do passado. Segundo a autora,

a ficção pós-moderna certamente procurou abrir-se para a história, para aquilo que Edward Said chama de "mundo" [...] E é uma espécie de paródia seriamente irônica que muitas vezes permite essa duplicidade contraditória: os intertextos da história assumem um status paralelo na reelaboração paródica do passado textual do "mundo" (HUTCHEON, 1991, p. 163. Grifos da autora).

Em Caramuru, o subtítulo - a invenção do Brasil - ironiza a pretensão à verdade na produção de imagens da história, chamando a atenção para a formação discursiva que inventou e transformou o descobrimento em evento fundador da nação. Ao assumir-se como invenção, a narrativa se

3 Produzida originalmente para televisão, a minissérie foi depois reeditada e adaptada ao formato de longa-metragem para exibição nas salas de cinema.

Cláudio Cledson Novaes, Fernanda Aguiar C. Martins, Roberto H. Seidel (Org.) 
reconhece ironicamente como um discurso entre outros no arquivo que instituiu as cenas das origens e da colonização brasileiras. Por isso mesmo, o termo invenção remete-nos, na minissérie-filme, como afirma Albuquerque Júnior (2007, p. 20), a uma leitura do evento histórico que "enfatiza a descontinuidade, a ruptura, a diferença, a singularidade", afirmando, portanto, "o caráter subjetivo da produção histórica".

Caramuru é um grande pastiche de crônicas dos viajantes do século 16 e de fontes historiográficas diversas, como O Descobrimento do Brasil, de Capistrano de Abreu, Visão do Paraíso, de Sérgio Buarque de Hollanda, História do Brasil, de Frei Vicente do Salvador, A Carta do achamento, de Caminha, Caramuru, poema épico do Frei José de Santa Rita Durão, As mais belas histórias da História do Brasil, adaptação romanesca do Caramuru feita por Viriato Corrêa, dentre outras. Visto como traço determinante do pós-modernismo, o pastiche caracteriza-se pela alusão intertextual de estilos do passado, visando não somente o escárnio ou a ruptura com estilos datados, mas também a homenagem ambivalente de textos-fonte da tradição canônica. Porém, por sua feição de comédia, $A$ invenção do Brasil não descarta a paródia como um procedimento textual importante. Aqui, a distinção entre pastiche e paródia proposta por Fredric Jameson é uma chave de leitura possível de Caramuru. Segundo o autor,

o pastiche, como a paródia, é o imitar de um estilo peculiar ou idiossincrático, é o colocar de uma máscara estilística [...] Mas é uma prática neutralizada de tal imitação, sem nenhum dos motivos inconfessos da paródia [...]. Desse modo, o pastiche é uma paródia branca (JAMESON, 1996, p. 44).

Caramuru ambienta-se na obscura fase "pré-colonial", os primeiros anos de "esquecimento" que sucederam ao "descobrimento da Terra de Vera Cruz", centrando-se na história mítica de Diogo Álvares Corrêa, jovem degredado português que, ao naufragar em praias baianas, foi rebatizado pelos índios como Caramuru. Pouco depois, reza a lenda, "casou-se com uma índia tupinambá, filha de um morubixaba, e uma espécie de morubixaba tornou-se também ele, constituindo uma curiosa aldeia mestiça, que reuniu europeus e ameríndios no litoral da Bahia quinhentista" (RISÉRIO, 2004 , p. 56). No prólogo do filme, Diogo se mete nas confusões que envolvem os mapas que teriam sido usados na viagem por Pedro Álvares Cabral. Por ser pintor, é contratado pelo cartógrafo do rei para ilustrar a carta naútica, mas acaba caindo nas tramas de uma cortesã francesa que ambiciona riqueza e relacionamentos com os poderosos. Após o roubo do mapa, Diogo é degredado para a América e "redescobre o Brasil" de forma nada 
heroica. Chega a terra flutuando num pequeno baú após um naufrágio, ao som de Miragem do Porto, de Lenine, que remete ao imaginário da visão do paraíso: "ê, lá no mar/ eu vi uma maravilha/ vi o rosto de uma ilha numa noite de luar [...] Quem vai lá no mar bravio não sabe o que vai achar [...] Eu sou aquele navio no mar sem rumo e sem dono [... $]^{\prime 4}$.

Ao retomar a figura de Caramuru, conferindo-lhe uma caracterização histriônica, falível e ex-cêntrica, muito distante do heroi épico nacionalista e mais próximo da tradição da novela picaresca, Furtado e Arraes deslocam o eixo da grande história da colonização para a epopeia menor de "um jovenzito comum, ordinário, da região do Minho" e à margem da nobreza, como lembra Risério. A minissérie-filme não quer, todavia, corrigir a lenda nem substituí-la por uma versão "mais verdadeira", mas, pelo contrário, imprimi-la desabusadamente, inventando origens alternativas, pois "o que ouvimos sobre ele são, no mais das vezes, lendas tardias, como aquela do tiro de arcabuz que teria espantado, seduzido e conquistado uma plateia de canibais. Mas essa proeza não passa de uma invencionice do jesuíta Simão de Vasconcellos, nos meados do século XVII" (RISÉRIO, 2004, p. 57).

Uma força a se destacar em Caramuru, aquela que o definiria como sintoma do pós-modernismo, refere-se à combinação não hierarquizada de estilos da tradição erudita em uma obra voltada à comunicação midiática, aproximando Pero Vaz de Caminha e Santa Rita Durão à comédia televisiva, neutralizando aquilo que Andreas Huyssen chama de "Grande Divisor", ou seja, o "discurso que insiste na distinção categórica entre alta cultura e cultura de massa", típica de certa tendência modernista, a qual alimentou uma radical hostilidade em relação à cultura popular massiva (HUYSSEN, 1997, p. 9). Produzida pela Rede Globo, um dos principais centros geradores da identidade nacional no Brasil, a minissérie-filme Caramuru está inserida em uma fronteira histórica entre "alta e baixa cultura", em um esquema de produção massiva, muitas vezes alérgico às experimentações formais do modernismo, mas, paradoxalmente, "dentro e fora, cúmplice, porém crítico", movido pelo lema pós-moderno do "vivam as margens!" (HUTCHEON, 1991, p. 103).

O filme de Arraes e Furtado pode ser lido também em conjunto com uma vertente significativa do romance brasileiro contemporâneo, aquela mais ajustada à ampla comunicação dos gêneros populares e midiáticos, como as tramas de ação e narrativas de aventura, hibridizados com irreve-

4 A canção foi lançada na trilha sonora original do filme, em 2001.

Cláudio Cledson Novaes, Fernanda Aguiar C. Martins, Roberto H. Seidel (Org.) 
rência com os clássicos da historiografia nacional. Exemplos dessa tendência são os romances Terra Papagalli (1997), de José Roberto Torero e Marcus Aurelius Pimenta; Boca do Inferno (1989) e Desmundo (1996), de Ana Miranda; O Xangô de Baker Street (1995), de Jô Soares; Viva o povo brasileiro (1984), de João Ubaldo Ribeiro; Agosto (1990), de Rubem Fonseca, dentre outros.

\section{IMAGENS DA CULTURA BRASILEIRA ALÉM DO CARTÃO-POSTAL}

O cinema brasileiro tem reiterado, em cada momento de sua trajetória, os esforços para definir os traços que compõem a identidade nacional. No campo cinematográfico, a "penosa construção de nós mesmos", que se "desenvolve na dialética entre o não ser e o ser outro", conforme a célebre frase de Paulo Emílio Salles Gomes (1980, p. 77), norteou o Cinema Novo, movimento criado por jovens cineastas brasileiros no início dos anos 1960, caracterizado pela experimentação formal e ênfase no universo mítico de setores marginalizados da sociedade brasileira: favelados, pescadores, retirantes, a violência no campo e na cidade, subúrbios, estádios de futebol, a religião popular, os sindicatos, meninos de rua, campesinos, dentre outros.

Glauber Rocha, figura medular do movimento, definia-se como um "cineasta nacionalista do Terceiro Mundo". Para ele, a revolução do Cinema Novo passaria inevitavelmente pela reavaliação crítica da nacionalidade. Glauber propôs um cinema faminto, com filmes que não apenas tomassem a fome como tema, mas que também fossem famélicos, assumidamente precários, refletindo a pobreza de seus meios de produção. A estética do filme seria um correlato objetivo do tema abordado: a pobreza material do estilo significaria a precariedade do mundo real. Tratava-se, naquele contexto, de um esforço radical de rever a condição "periférica" da cultura brasileira dentro da agenda de um novo projeto de modernidade, que traçasse um destino utópico para a nação. Enfim, o Cinema Novo insere-se nos processos de modernização e de nacionalização da cultura, como um agenciamento de reconstrução incessante da imagem nacional.

$\mathrm{Na}$ invenção da autorepresentação do País, o cinema brasileiro priorizou dois territórios simbólicos da nação: o sertão e a favela - locações privilegiadas, marcadas pelas tensões e contradições de uma modernidade inacabada. Em um artigo nodal, Ivana Bentes grifa a persistência, no âmbito do cinema, desses espaços na interpretação do País: 
Territórios de fronteiras e fraturas sociais, territórios míticos, carregados de simbologias e signos, sertão e favela sempre foram o "outro" do Brasil moderno e positivista: lugar da miséria, do misticismo, dos deserdados, nãolugares e, simultaneamente, espécies de cartão-postal perverso, com suas reservas de "tipicidade" e "folclore", quando tradição e invenção são extraídas da adversidade [...] Na passagem do Brasil rural ao urbano, tematizada no cinema dos anos 1960, os sertanejos transformaram-se em favelados e suburbanos, "ignorantes e despolitizados", mas também em rebeldes primitivos e revolucionários, capazes de mudanças radicais, como nos filmes de Glauber (BENTES, 2007, p. 191).

Desde o fim dos anos 1950, sobretudo com o lançamento do clássico Rio, 40 Graus, de Nelson Pereira dos Santos, críticos e diretores influenciados pelas lições do Neo-Realismo italiano - câmeras soltas nas ruas, filmes de baixo orçamento com temáticas sociais e humanistas - elegeram as favelas brasileiras como outro território simbólico da identidade nacional. As periferias da nação, assim como o sertão, permanecem ainda hoje um nervo central no conjunto das questões sociais representadas pelo cinema brasileiro, sendo retomadas em várias produções do chamado Novo Cinema, bastando lembrar filmes recentes como Verônica (Maurício Farias, 2009), Linha de passe (Walter Sales e Daniela Thomas, 2008), Última Parada - 174 (Bruno Barreto, 2008), Os 12 Trabalhos (Ricardo Elias, 2007), Tropa de Elite (José Padilha, 2007), O Homem do Ano (José Henrique Fonseca, 2006), Cidade de Deus (Fernando Meirelles e Kátia Lund, 2002), O Invasor (Beto Brant, 2001), dentre outros. Por questão de concentração, comentarei rapidamente apenas os dois últimos.

Em O Invasor, baseado na novela de Marçal Aquino, escrita em paralelo à produção do filme, o diretor Beto Brant apresenta a história de Gilberto e Ivan, dois engenheiros paulistas, proprietários de uma construtora, que resolvem eliminar um outro sócio e amigo, depois que este último se recusa a participar de um negócio ilícito com o governo. Para resolver o "empecilho", contratam Anísio, um matador da periferia de São Paulo, que, após o serviço, decide se "integrar" à empresa dos mandantes, com sérias complicações: os engenheiros foram à periferia para encomendar o crime; por isso, Anísio vai ao centro para ocupar o lugar de "sócio", que considera seu e de direito, após ter limpado o caminho dos mandantes.

Depois de "invadir a praia" dos dois empresários, Anísio passa a ser o centro gravitacional da trama. Ele é assustadoramente engraçado e um híbrido de malandro e marginal barra-pesada, cuja presença invasiva estabelece um embate simbólico entre a periferia e o centro, entre a carência material e a boa vida dos ricos. O filme se destaca em relação a outras pro-

Cláudio Cledson Novaes, Fernanda Aguiar C. Martins, Roberto H. Seidel (Org.) 25 
duções de temática semelhante por tratar, sem o verniz da cordialidade e do paternalismo, a continuidade entre a violência e o mundo dos negócios, entre o crime e a cultura empresarial. Quem invade a área de quem? Quem é o invasor? Brant embaralha essas perguntas e escapa à tendência mais usual da representação dos conflitos sociais em nichos específicos: os ricos, acossados pelos Outros, e os excluídos isolados ou em leve conciliação.

Daí que, em $O$ Invasor, os personagens circulem incessantemente entre os espaços segregados da cidade. Esses percursos dentro da metrópole, com longas sequências em travellings, chamam atenção para as conexões entre periferia e centro, entre as áreas de exclusão social e o capitalismo urbano. De início, são os empresários que se deslocam às margens de São Paulo no contato com Anísio, que, em uma sequência posterior, irá à mansão de Marina, a filha do sócio assassinado, para em seguida levá-la em uma aventura pelas favelas. O epílogo desta viagem, ao som do rap, mostrando, conforme Zanin Oricchio (2003, p. 177), "o casal transando dentro do carro e tendo a cidade lá embaixo, digamos assim, a seus pés", tem uma função importante na pauta do filme, pois sinaliza para as ligações ocultas entre espaços simbolicamente apartados mas comunicantes nos circuitos de trocas sociais.

Em outra sequência importante, vemos o empresário Ivan, aparentemente arrependido pelo crime, se envolver, em um cruzamento, numa colisão com um carro mais velho, cujos ocupantes "são dois manos da periferia". A batida se dá numa via urbana que corta uma favela. Na discussão que se segue, esboça-se uma situação de conflito. Mas aqui o roteiro trai a expectativa mais comum, pois a violência armada vem do "branco rico", já que é Ivan quem saca uma arma apontando-a na direção daqueles que pertencem, é claro, "ao outro lado da sociedade". É dessa trombada entre diferentes que

nasce toda a força do filme. Mas, é claro, uma dramaturgia convencional diria que o diretor perde muito tempo indo de um lugar a outro. É que, em $O$ Invasor, o real não está na partida nem na chegada, mas se dispõe no meio do caminho, como dizia Riobaldo, o narrador de Grande Sertão: veredas, de Guimarães Rosa (ORICCHIO, 2003, p. 178).

Outra característica inusitada de $O$ Invasor é o tratamento dado ao tema da violência que vem marcando as narrativas literárias e audiovisuais na atualidade, como se a violência tivesse se tornado um operador de leitura incontornável à compreensão dos dilemas do País. Beto Brant e Marçal Aquino escaparam da tendência à explicitação da crueldade, realizando um 
filme sobre a violência, no qual não há, ao longo da ação, um único disparo ou sequer uma gota de sangue (com exceção apenas de uma cena em que vemos rapidamente sinais de sangue na mala do carro do sócio assassinado). Aqui, a violência é anunciada e respirada, mas permanece "invisível" e quase nunca representada diretamente. Por ser também "virtual" e "simbólica", a violência torna-se, portanto, ainda mais desconfortante para o espectador. A violência, parece nos dizer $O$ Invasor, se torna mais terrível quando imaginada e mais tenebrosa ainda por se manifestar através da linguagem cotidiana. Em suma, $O$ Invasor recorta de lado a lado o tecido social da metrópole e expõe os vínculos entre as partes da pirâmide social que a compõem, tornando-se uma representação sem complacências dos confrontos e impasses que marcam a sociedade brasileira contemporânea, rasurando as bases da auto-imagem harmonizadora da identidade nacional.

Cidade de Deus, dirigido por Fernando Meirelles e Kátia Lund, é o mais importante e polêmico filme do Cinema Brasileiro da última década. A história se passa em um único espaço: o conjunto habitacional Cidade de Deus, na zona oeste do Rio de Janeiro, fundado para receber moradores de favelas removidas pelas enchentes ou destruídas na política de "limpeza urbana" do governo carioca no final dos anos 1960. Para lá se mudam duas crianças, Dadinho e Busca-Pé, cujo irmão mais velho, Marreco, forma com os amigos Cabeleira e Alicate o "Trio Ternura", cuja especialidade é assaltar caminhões de gás, entre outros pequenos roubos. Cansados de serem "bandidos merrecas", resolvem assaltar um motel de "classe-média". Dadinho, que acompanha o grupo e sonha ser bandido temido e "bicho-solto", resolve entrar em cena e assassinar clientes e funcionários do motel. A notícia da chacina é suficiente para que a comunidade ganhe "visibilidade" na mídia e seja inserida - pela opinião pública - no imaginário nacional como um dos lugares mais perigosos da cidade. Baseado no romance homônimo de Paulo Lins, morador da Cidade de Deus, o filme propõe uma genealogia do crime organizado no Rio de Janeiro, a partir das transformações pelas quais passa a favela do título. A ação atravessa três momentos - dos anos 1960 até o início dos 80 -, cada qual com características estéticas distintas, cuja intenção é mapear os motivos do crescimento da violência. Partindo do roteiro do filme, seguimos o desenrolar da trama em três movimentos, a saber:

a) a 1ㅁ fase corresponde ao final dos anos 60 quando da inauguração do conjunto Cidade de Deus. No nível da linguagem, predominam os planos gerais do espaço e o ambiente aberto, que simbolizam a 
perspectiva de um novo horizonte. Há predominância de cenas diurnas em exteriores e a trilha sonora privilegia temas percussivos e ritmos brasileiros misturados a sambas clássicos da época. No plano das representações do crime, os bandidos são do tipo mais romântico, consomem maconha e utilizam armas de pequeno porte. Na cena do assalto ao caminhão de gás, por exemplo, os assaltantes comportam-se como se fossem caubois de um western, numa abordagem de uma diligência, dividindo parte do roubo com a comunidade;

b) o 20 movimento apresenta os novos espaços da favela, os chamados "apês", conjuntos habitacionais verticais construídos no âmbito do projeto de "moradias populares" durante o "milagre econômico" apregoado pelo governo militar. Nesse momento, o uso da câmera na mão visa provocar a sensação de instabilidade e confinamento da comunidade em compasso com o aumento da violência, o surgimento de armamento mais pesado e a chegada do tráfico e do consumo de cocaína. O horizonte aberto praticamente desaparece, predominando as imagens de becos labirínticos que terminam em muros cerrados, sem as linhas de fuga e perspectivas abertas do início. A trilha sonora apresenta clássicos da soul music, do funk e do samba-rock que embalavam os bailes black da época;

c) o 30 ato se passa durante a transição dos 70 para os 80 . Marca o auge do poder de Dadinho, agora rebatizado como Zé Pequeno, lutando pelo território do tráfico contra outro traficante da área, Cenoura, que se alia a Mané Galinha, um ex-cobrador de ônibus, cuja família é vítima da violência imposta por Pequeno. No nível da linguagem, agora se perde qualquer unidade estilística, optando-se por uma estética suja, com planos rápidos e fragmentados, que intensificam a tensão do drama e a sensação de instabilidade no ápice da violência. É o momento em que eclode a guerra entre as facções pelo monopólio do tráfico de cocaína, negócio em franca expansão.

Há, no filme, diferenças suplementares em relação ao romance de Paulo Lins. A primeira é o foco: no livro, Busca-Pé é um dos muitos personagens que surgem e desaparecem na narrativa, contada por um narrador difuso, porém sujeito da história, que não se fixa em um personagem específico. No filme, Busca-Pé é o narrador principal, que conta sua trajetória 
para fugir do crime. A outra diferença é que o filme é mais "otimista" se comparado ao livro, que expõe as máculas sociais mais frontalmente. $\mathrm{Na}$ fita, Busca-Pé, após fotografar um acordo de Zé Pequeno com a polícia, consegue um "trampo" de estagiário de fotografia em um jornal, mostrando sua opção pelo "caminho do bem", como diz a letra da canção de Tim Maia que encerra o filme. Por outro lado, em paralelo ao salto dado por Busca-Pé, a sequência final mostra-nos que, se um garoto escapou temporariamente ao ciclo cruel da violência, outros, "os pivetes da Caixa-Baixa", não escapam do way of life do crime, e chegam, após um rito de passagem - o assassinato de Zé Pequeno - ao "poder" da favela. Eis um detalhe importante: o desfecho do filme apresenta uma imagem pouco otimista socialmente. A escalada ascendente da violência é concomitante com a diminuição da idade dos "novos bandidos", garotos na faixa dos seis aos dez anos de idade, pequenos sísifos armados e amadurecidos pela guerra, que empurram a rocha e a rixa para o labirinto da neofavela. A morte de Zé Pequeno não resulta, portanto, no fim do crime e nem estabiliza o mundo. O que fica, nessa estranha catarse, é uma compreensão atordoante, incômoda e sem as redenções reconfortantes mais usuais.

Podemos dizer que o filme e ainda mais o livro Cidade de Deus fazem emergir uma visão das identidades culturais e suas margens, sem a fetichização do outro, bem comum nas narrativas nacionais, que buscavam, a partir dos parâmetros de cada época, reproduzir conciliatoriamente as relações que cortam o corpo da nação. Lins não fala "sobre e para os excluídos", mas como um "ex-cêntrico de dentro da favela", ativando "outra construção discursiva do nacional, que, hegemonicamente, tem priorizado, ora a voz, ora o olhar do centro para ficcionalizar o imaginário coletivo da nação" (MELO, 2000, p. 144). Porém, não se quer dizer que exista uma "verdade da favela", que possa ser preenchida ontologicamente, reificando o "marginal" como a única chave de compreensão da nacionalidade; mas que as margens permanecem rasurantes e transversais nessa zona instável e dispersa que é a nação. Cidade de Deus não solicita qualquer estabilidade redentora para a identidade nacional; ao contrário, procura cartografar as dessimetrias da cultura contemporânea e outras maneiras de narrar esse "claro enigma" que chamamos de Brasil.

\section{REFERÊNCIAS}

AQUINO, Marçal. O invasor. São Paulo: Geração Editorial, 2002.

ALBUQUERQUE JR., Durval Muniz. História: a arte de inventar o passado. Bauru: EDUSC, 2007. 
ANDERSON, Benedict. Comunidades imaginadas: reflexões sobre a origem e a difusão do nacionalismo. São Paulo: Companhia das Letras, 2008.

BENJAMIN, Walter. Magia e técnica, arte e política: ensaios sobre literatura e história da cultura. São Paulo: Brasiliense, 1985.

BENTES, Ivana. (Org.). Ecos do cinema: de Lumière ao digital. Rio de Janeiro: Ed. UFRJ, 2007. COLI, Jorge. Primeira Missa e invenção da descoberta. In: NOVAES, Adauto. (Org.). A descoberta do homem e do mundo. São Paulo: Companhia das Letras, 1998.

COUSINS, Mark. Historia del cine. Barcelona: Blume, 2004.

CUNHA, Eneida Leal. Ainda a Carta de Caminha. Qvinto Império: Revista do Centro de Estudos Portugueses, n. 4, jun. 1995. Salvador: Casa Fernando Pessoa; Gabinete Português de Leitura.

GOMES, Paulo Emílio. Cinema: trajetória no subdesenvolvimento. Rio de Janeiro: Paz e Terra, 1980.

HALL, Stuart. As culturas nacionais como comunidades imaginadas. In: Id. Identidade cultural na pós-modernidade. Rio de Janeiro: DP\&A, 2006.

HUYSSEN, Andreas. Memórias do modernismo. Rio de Janeiro: Ed.UFRJ, 1997.

HUTCHEON, Linda. Poética do pós-modernismo: história, teoria, ficção. Rio de Janeiro: Imago, 1991.

JAMESON, Fredric. Pós-modernismo: a lógica do capitalismo tardio. São Paulo: Ática, 1996.

LINS, Paulo. Cidade de Deus. São Paulo: Companhia das Letras, 2007.

MEIRELLES, Fernando; MANTOVANI, Bráulio. Cidade de Deus - Roteiro. Rio de Janeiro: Objetiva, 2003.

MELO, Cléa Corrêa de. O desafio crítico de Cidade de Deus. Revista Tempo Brasileiro, n. 141, abr.-jun. 2000. Rio de Janeiro: Tempo Brasileiro.

NAGIB, Lucia. A utopia no cinema brasileiro: matrizes, nostalgia, distopias. São Paulo: Cosac Naify, 2006.

OLIVEIRA, Marinyze Prates de. Olhares roubados: cinema, literatura e nacionalidade. Salvador: Quarteto, 2004.

ORICCHIO, Luiz Zanin. Cinema de novo: um balanço crítico da retomada. São Paulo: Estação Liberdade, 2003.

RISÉRIO, Antonio. Uma história da Cidade da Bahia. Rio de Janeiro: Versal Editores, 2004.

ROCHA, João Cezar de Castro. Dialética da Marginalidade. Folha de S. Paulo (Caderno Mais!, 04). São Paulo, 29 de fevereiro de 2004.

SCHWARZ, Roberto. Cidade de Deus. In: Id. Sequências brasileiras: ensaios. São Paulo: Companhia das Letras, 1999.

SCHVARZMAN, Sheila. Humberto Mauro e as imagens do Brasil. São Paulo: Ed. UNESP, 2004.

STAM, Robert. Cinema e Multiculturalismo. In: XAVIER, Ismail. (Org.). O cinema no século. Rio de Janeiro: Imago, 1996. 